STERLING'S PAST, DOLLAR'S FUTURE:

HISTORICAL PERSPECTIVES ON RESERVE CURRENCY COMPETITION

Barry Eichengreen

Working Paper 11336 
NBER WORKING PAPER SERIES

STERLING'S PAST, DOLLAR'S FUTURE:

HISTORICAL PERSPECTIVES ON RESERVE CURRENCY COMPETITION

\author{
Barry Eichengreen \\ Working Paper 11336 \\ http://www.nber.org/papers/w11336 \\ NATIONAL BUREAU OF ECONOMIC RESEARCH \\ 1050 Massachusetts Avenue \\ Cambridge, MA 02138
}

May 2005

The views expressed herein are those of the author(s) and do not necessarily reflect the views of the National Bureau of Economic Research.

C2005 by Barry Eichengreen. All rights reserved. Short sections of text, not to exceed two paragraphs, may be quoted without explicit permission provided that full credit, including (C) notice, is given to the source. 
Sterling's Past, Dollar's Future: Historical Perspective on Reserve Currency Competition Barry Eichengreen

NBER Working Paper No. 11336

May 2005

JEL No. F0

\begin{abstract}
This paper provides an historical perspective on reserve currency competition and on the prospects of the dollar as an international currency. It questions the conventional wisdom that competition for reserve-currency status is a winner-take-all game, showing that several currencies have often shared this role in the past and arguing that innovations in financial markets make it even more likely that they will do so in the future. It suggests that the dollar and the euro are likely to share this position for the foreseeable future. Hopes that the yuan could become a major international currency 20 or even 40 years from now are highly premature.
\end{abstract}

\author{
Barry Eichengreen \\ Department of Economics \\ University of California \\ 549 Evans Hall 3880 \\ Berkeley, CA 94720-3880 \\ and NBER \\ eichengr@econ.berkeley.edu
}




\section{Sterling's Past, Dollar's Future: Historical Perspectives on Reserve Currency Competition ${ }^{1}$ \\ Barry Eichengreen \\ University of California, Berkeley \\ April 2005}

One can hardly pick up a financial newspaper these days without seeing a story on the dollar's impending loss of international preeminence. This may simply reflect the instinctual tendency for financial journalists to find a seat on the nearest bandwagon and ride it for all it is worth. As Mark Twain might have said, reports of the dollar's death have been greatly exaggerated. The dollar is still the dominant reserve currency for central banks and governments. The share of international reserves in dollars has actually been rising, not falling. The market in U.S. treasury securities is still the single most liquid financial market in the world, which makes it attractive for central banks to hold their reserves in this form. The dollar is still the dominant invoicing and vehicle currency in international trade. Petroleum and other commodities are still invoiced in dollars.

There are, of course, good reasons for questioning whether this will remain the case. The dollar has fallen by 16 percent on a trade weighted basis from its peak at the beginning of the decade. More importantly, never before have we seen the extraordinary situation where the country issuing the leading international currency is running a current account deficit of 6 percent of GDP. Never before have we seen the reserve currency country in debt to the rest of the world to the extent of 25 percent of GDP. The connections between U.S. budget deficits, themselves partly a reflection of the country's overseas military commitments, and the weakness of the currency suggest parallels with the trials of the dollar in the 1960s and the tribulations of sterling after World War II. All

\footnotetext{
${ }^{1}$ Text of the Tawney Lecture, delivered to the Economic History Society, Leicester, 10 April 2005.
} 
this is bound to raise questions in the minds of foreign holders of U.S. treasury securities that may lead them to search for alternative forms in which to hold their claims. And for the first time in living memory there exists another currency with a deep and liquid market issued by an economy as large as the United States. That currency, obviously, is the euro. Looking forward there is also the renminbi, the currency of an economy that 50 years from now may be even larger economically and trade more extensively than the United States.

History is widely invoked in discussions of this issue, even by currency forecasters who are typically more comfortable with tick-by-tick data than archival sources. Consider the following quote from Avinash Persaud of State Street Bank and Trust. " $[R]$ eserve currencies come and go. Over the past two and a half thousand years there have been over a dozen reserve currencies that no longer exist. Sterling lost its status in the first half of the $20^{\text {th }}$ century, [and] the dollar will lose its status in the first half of this century...Losing reserve currency status will lead to a series of economic and political crises in the United States."

While this passage is exceptional for its drama, it is not unusual for its history. This is not surprising, since a change in the dominant international currency is not seen very often. The last time such a shift occurred, from sterling to the dollar, was more than half a century ago. Moreover, if we focus on one specific role of an international currency, as a store of value for central banks' and governments' international reserves, one can argue that this was the only such shift in recorded history. ${ }^{3}$ Other monetary units had come in for international use before, but not as a form in which to hold liquid paper

\footnotetext{
${ }^{2}$ Persaud (2004), p. 1.

${ }^{3}$ Here,obviously, I am dissenting from one of Persaud's assertions.
} 
liabilities in connection with the operation of the international monetary system. Most medieval and early modern examples of "international money" were simply coins that circulated for use across national borders. In the $17^{\text {th }}$ and $18^{\text {th }}$ centuries when Holland was a leading international commercial and financial power and Amsterdam was a leading international financial center, paper claims became important but most international operations there were in bills on foreign places, not in claims on the Dutch government itself. $^{4}$

In the remainder of this lecture I will focus on the dollar's role as the dominant form of official reserves and its place in the operation of the international monetary system. There is a sense, therefore, in which we really have only one data point, the transition from sterling to the dollar, from which to draw inferences. Thus, we are truly in the historian's domain.

$* * * *$

As I just suggested, while foreign deposits and purchases of foreign bills and bonds are nothing new, large-scale holdings in foreign financial centers by central banks and governments are a relatively recent development. The spread of this practice coincided with the emergence of the international gold standard in the decades prior to World War I. With a few important exceptions, the standard in question was a gold bullion standard, not a gold coin standard. ${ }^{5}$ A significant share of the monetary circulation of countries on the gold standard was not gold coin, in other words, but token

\footnotetext{
${ }^{4}$ See Wilson (1941) and Lindert (1969).

${ }^{5}$ Gold coin constituted a large share of the circulation only in England, France, Germany, the United States, Russia after 1897, Australia, South Africa and New Zealand according to Bloomfield (1959).
} 
coins and paper convertible into gold bullion under certain circumstances. The gold bullion standard was a $19^{\text {th }}$ century innovation. It presupposed a uniform currency that was difficult to counterfeit, which became possible only when steam power came to the mint. ${ }^{6}$ Once gold was concentrated in the vaults of central banks (or in treasuries and other note issuing banks where there existed no central bank), there was an incentive to substitute or at least augment it with bills and deposit claims which bore interest but were convertible into gold. Peter Lindert's estimates, which nearly four decades after their appearance are still the best available, suggest that foreign exchange rose from a tenth to a seventh of global international reserves between 1880 and $1914 .^{7}$

Why London should have been the place where many such reserves were maintained and why sterling bills and deposits should have been their single most important form are easy enough to understand. Britain was the world's preeminent trading nation, absorbing more than 30 percent of the exports of the rest of the world in 1860 and 20 percent in $1890 .{ }^{8}$ It was a leading exporter of manufactures and services and also a voracious consumer of imported foodstuffs and raw materials. Between 1860 and 1914 probably about 60 percent of world trade was invoiced and settled in sterling. ${ }^{9}$ For foreign suppliers seeking to sell, say, cotton, quoting prices in sterling was helpful for breaking into the British market. The supplier would maintain a deposit account in London where receipts could be held safely for at least short periods. With the growth of

\footnotetext{
${ }^{6}$ See Redish (1990) and the author's other publications on this subject.

${ }^{7}$ See Lindert (1969). They then rose further, to roughly a quarter of global reserves, in the 1920s, prompting observers to write, with something of a lag relative to reality, of the emergence of a goldexchange standard.

${ }^{8}$ According to the famous estimates of Imlah (1958).

${ }^{9}$ Williams (1968), p. 268.
} 
imports and re-exports of these materials came the development of commodity exchanges where both spot and forward prices were similarly quoted in sterling. ${ }^{10}$

Britain's position as the single most important source of long-term overseas investment worked in the same direction. Foreign governments seeking to borrow abroad came to London, making sterling the logical unit of account for debt securities, since then as now there was a limited appetite for bonds denominated in their own currencies, the markets in which were less liquid and whose value was more easily manipulated by the issuer. ${ }^{11}$ When funds became available, it was natural to park them temporarily in deposit accounts in London, generally in the same bank that had underwritten the loan. ${ }^{12}$ Lenders encouraged the practice on the view that the maintenance of deposits in London was a bonding device that might promote good behavior on the part of the borrower. ${ }^{13}$

That Britain was an imperial power reinforced sterling's role. From the early $18^{\text {th }}$ century a conscious effort was made to encourage the use of the pound throughout the empire as a way of simplifying and regularizing transactions. ${ }^{14}$ British financial institutions established branches in the colonies, and colonial banks opened offices in London. These banks maintained assets and liabilities in London and issued bank notes for the colonies, maintaining a fixed exchange rate between those notes and sterling. When those exchange rates misbehaved, the British government imposed direct regulation of local currency issues, notably featuring full external convertibility of the local currency into sterling at a fixed rate of exchange, something that was maintained by

\footnotetext{
${ }^{10}$ Forward contracts in sterling traded in Liverpool from at least the $1850 \mathrm{~s}$.

${ }^{11}$ On this, see Flandreau and Sussman (2005) and Bordo, Meissner and Redish (2005). In the case of colonial and Commonwealth borrowers, the entire question of currency denomination was moot, of course.

${ }^{12}$ More so to the extent that they eventually were going to be used to purchase machinery, railway rolling stock and other products of British industry.

${ }^{13}$ See Balogh (1950), although it can be questioned, as Lindert does, whether it was the lender or the borrower whose behavior was most constrained by the practice.

${ }^{14}$ See for example Crick (1948).
} 
buying and selling sterling on demand in London. In cases like India where the British sovereign was ultimately made legal tender, the colonial government was led to establish a sizeable reserve in London.

These practices further enhanced the liquidity of the London market, which was probably the single most important fundamental making it attractive for foreign central banks and governments to hold interest-bearing assets there in the first place. Because the market was deep and liquid, official foreign holders of sterling could augment and deplete their positions without disturbing prices or revealing facts about their balance sheets. They could use sterling to intervene in the foreign exchange market to prevent their exchange rates from straying beyond the gold import and export points. Although problems in the London market did arise periodically, these never jeopardized the convertibility of sterling. And while the Bank of England occasionally resorted to the gold devices, modifying the effective price of gold, it never seriously interfered with the freedom of nonresidents to export gold. Few if any other financial centers could claim all these attributes. $^{15}$

Sterling's preeminence prior to 1914 is frequently invoked as evidence that there can be only one international currency at any point in time. Then it was the pound, now it is the dollar, and in the future it will be something else. To again quote Persaud, "at any one point in time, there tends to be a single dominant currency in the financial world, not two or more, just one. Some people believe that the euro may not topple the dollar, [but

\footnotetext{
${ }^{15}$ Bloomfield (1959) notes that both the Bank of France and German Reichsbank, which oversaw the operation the main competing reserve centers, took various steps in the period to make it difficult for market participants to export gold.
} 
that] it will at least share some of the spoils of financial hegemony. History suggests not. In the currency markets the spoils go to the victor, alone; they are not shared."16

The notion that there is room in the market for only one reserve currency is based on the concept of network externalities and on the singular dominance of the dollar in the final quarter of the $20^{\text {th }}$ century. ${ }^{17}$ The network-externalities story is that, as with computer operating systems, there are strong incentives to conform to the choice that dominates the marketplace. ${ }^{18}$ But while this argument carries some weight in the choice of currency for invoicing trade or denominating foreign debt securities, it is less obviously valid for the currency of denomination of reserves. ${ }^{19}$ It may pay to hold reserves in the most liquid market, which tends to be the market in which everyone else holds reserves, but market liquidity is not all that matters. It may be worth tolerating a bit less market liquidity in return for the benefits of greater diversification or as an expression of good faith to the investment bank that one seeks to have underwrite one's loans. And if there is no strong network externality encouraging one to hold reserves in the same currency as other central banks, then there is no lock-in to prevent central banks from altering the currency composition of their reserve portfolios in response to new information about expected capital gains and losses.

In fact, the historical evidence is not obviously consistent with the notion that the spoils in currency markets go to the victor alone. At the end of 1913, sterling balances

\footnotetext{
${ }^{16}$ Persaud (2004), p. 1.

${ }^{17}$ To again quote Persaud (p. 2), "Reserve currencies have the attributes of a natural monopoly or in more modern parlance, a network. If it costs extra to trade with some one who uses a different currency than you, it makes sense for you to use the currency that most other people use, this makes that currency yet bigger and cheaper to use. There is a good analogy with computers. "Windows' is the dollar of operating systems."

${ }^{18}$ This is the analytical basis for formal models of international currency status. See for example Matsuyama, Kiyotaki and Matsui (1993).

${ }^{19}$ Readers familiar with my own previous work on this subject (Eichengreen 1998) will notice that my views on this particular issued have evolved, as views will sometimes do.
} 
accounted for less than half of the total official foreign exchange holdings whose currency of denomination is known, while French francs accounted for perhaps a third and German marks a sixth. ${ }^{20}$ (See Table 1.) Over the preceding quarter century, sterling's share had in fact been falling, not rising, mainly in consequence of the growing share of the French franc. In Europe itself, sterling was a distant third as a form in which to hold official reserves behind both the franc and the mark.

Nor is interwar experience obviously consistent with the notion that one currency dominates international usage. In the 1920s and 1930s three currencies again shared this role, although now the dollar supplanted the German mark. The establishment of the Federal Reserve System in 1914 had enhanced the liquidity of the New York market and heightened its attractions as an international financial center. Indeed, elevating its status in this way was one of the motivations for founding the Fed in the interpretation of Lawrence Broz. ${ }^{21}$ Before World War I the dollar was scarcely used in international transactions. ${ }^{22}$ There existed no central bank to rediscount those acceptances, purchase bills on the open market, and otherwise ensure the liquidity of the market. This changed of course with the founding of the Fed.

World War I had a reinforcing effect. Germany suspended convertibility in the opening week of the war. The Bank of France, which had never been legally obliged to convert notes into gold, did so only under exceptional circumstances before an official gold embargo was imposed in 1915. Britain restricted the export and melting of gold in

\footnotetext{
${ }^{20}$ Lindert (1969), Table 3. Note the qualification in the text: these calculations exclude from consideration the $\$ 232$ million whose currency of denomination is not known.

${ }^{21}$ See Broz (1997).

${ }^{22}$ This reflected the absence of a deep and liquid market in bankers acceptances, which was itself a reflection of the fact that national banks were prohibited from accepting bills of exchange arising out of international trade.
} 
1917. The United States, in contrast, preserved gold convertibility even after it entered World War I, in $1917 .^{23}$ Its shares of global trade and foreign lending were then markedly higher in the 1920s than they had been before World War I, leading to a considerable expansion in the dollar's role as a unit of account and means of payment for international transactions between private parties. Germany and France suffered financial turmoil in the first half of the 1920s. In the second half of the decade the Bank of England was continuously "under the harrow," in Montagu Norman's famous phrase. ${ }^{24}$

And yet, despite all this, sterling, the dollar, and the franc shared the reserve currency role in the 1920s and 1930s. It is striking that we still lack careful Lindert-like estimates of the relative shares of the three currencies. But sterling was probably still first, followed by the dollar and the franc. ${ }^{25}$

The conventional wisdom that one currency dominates reserve holdings worldwide thus derives mainly from the second half of the $20^{\text {th }}$ century alone, when the greenback accounted for as much as 85 percent of global foreign exchange reserves. (See Table 2.) In part, the post-World War II dominance of the dollar reflected the exceptional dominance by the United States of global trade and payments in a period when Europe and Japan had not yet fully recovered from the war and modern economic growth had yet

\footnotetext{
${ }^{23}$ In 1914 it induced the New York banks to establish a gold pool for financing balance-of-payments settlements, and after the country entered the war the government appealed to patriotism and erected various modest bureaucratic obstacles to discourage private gold exports. But, fundamentally, it was the strength of the U.S. balance of payments, given the country's status as a leading producer of manufactured exports and raw materials for the war effort, that allowed it to maintain convertibility in this difficult period.

${ }^{24}$ Sayers (1976), p. 211.

${ }^{25}$ Triffin (1964) provides an estimate for 1928 of official reserves in dollars of $\$ 600$ million, versus $\$ 2,560$ million in other currencies. He estimates the reserves denominated in dollars then fell to $\$ 60$ million at the end of 1933, with the collapse of the gold-exchange standard, while reserves denominated in other currencies fell to $\$ 1,055$. Reserves in those other currencies may have been split 70/30 between sterling and the French franc, with a higher fraction probably being held in francs after 1931 when the convertibility of sterling into gold was suspended and the currency was allowed to float. See Nurkse (1944) and Bell (1956).
} 
to spread to what we now refer to as emerging markets. ${ }^{26}$ In addition it reflected the fact that the governments of other potential reserve centers actively discouraged international use of their currencies. Germany saw the internationalization of the deutschemark as a threat to its control of inflation. Japan saw the internationalization of its currency as incompatible with their systems of directed credit. France had seen more than once how allowing private foreign funds to move in also allowed them to move out if investors concluded that the government's macroeconomic policy aspirations were incompatible with its putative commitment to currency stability. These and other considerations led the countries whose currencies were potential alternatives to the dollar to maintain significant capital controls well into the post-World War II period, in some cases until the end of the 1980s. Controls limited the liquidity of their securities markets. ${ }^{27}$ Thus, it was not simply the unusually large size of the U.S. in the world economy or the admirable liquidity of U.S. financial markets but the maintenance of controls by other potential reserve centers that explains why the dollar was so dominant in reserves for so long after World War II. While most of these controls were relaxed or removed by the 1990s, that decade was marked by a slump in Japan and the uncertain transition to the euro, making it an unpropitious time for radical portfolio reallocation. In addition the rapid growth of the American economy, especially in the second half of the 1990s, meant that the dominance

\footnotetext{
${ }^{26}$ In fact, the raw data do not suggest that the dollar dominated the market for international reserves until the end of the 1950s. But the earlier period was one of significant disequilibrium: it was the years of the "dollar shortage," and the large sterling balances held by members of the Commonwealth and Empire were blocked (that is, not held entirely voluntarily). Indeed, more than half of global foreign exchange reserves were held in sterling in 1949, and some 36 percent was held in this form in 1957. An indirect guide to the share of reserves that might have been held voluntarily was the share of the sterling area in global trade, which was about 30 percent in this period.

${ }^{27}$ In conjunction with the bank-based nature of their financial systems, as emphasized by Rajan and Zingales (2003).
} 
of the dollar troubled few reserve managers. The question now is whether this might change.

But is not the persistence of sterling's reserve-currency role into the second half of the $20^{\text {th }}$ century, long after the United Kingdom's international commercial and financial preeminence passed, evidence that reserve currency status, once gained, is hard to lose? I am not convinced. After World War II, sterling reserves were held not because of any lingering incentives conferred by network externalities but mainly as a matter of loyalty by members of the Commonwealth and by colonies with limited choice in the matter. $^{28}$

Another reason, in addition to loyalty, that members of the Sterling Area were reluctant to more quickly diversify their reserves out of sterling was that they recognized that doing so might aggravate the problems of the British economy, on which they depended as a market for their exports. They valued the exchange-rate and financial stability conferred by the greater sterling area and were reluctant to precipitate its breakup. ${ }^{29}$ This position became less tenable following the 1967 devaluation, when capital losses were once more imposed on sterling-area countries. This led to the negotiation of the Basle Facility of 1968 and the associated bilateral agreements in which the UK guaranteed the value in dollars of the official sterling reserves of sterling area countries, in return for which each partner country pledged not to reduce its official sterling balances beyond a certain point.

This observation has inspired confidence in some circles that foreign central banks and governments today will similarly resist the temptation to diversify their

\footnotetext{
${ }^{28}$ Although, as noted by inter alia Schenk (2004), the colonies did possess a significant and growing amount of fiscal and financial autonomy after World War II, and especially in the 1960s.

${ }^{29}$ For discussion of this point see Cohen (1971).
} 
reserves, since they know that doing so may precipitate a sharp drop in the dollar exchange rate and damage their prospects for export-led growth. ${ }^{30}$ This interpretation misses the distinction between the individual interest and the collective interest. ${ }^{31}$ The relevant historical precedent here is the Gold Pool. ${ }^{32}$ Established in 1961, the Gold Pool was an arrangement whereby central banks sought to share the cost of maintaining the London price of gold at $\$ 35$ an ounce rather than depleting U.S. gold reserves. It encouraged collective action by establishing an understanding of how the costs of those operations would be divided - that is, of what share of the gold that needed to be sold in London in order to stabilize the market price would be provided by each participating central bank. It collapsed in 1968 after French gold purchases became known and was followed in short-order by the collapse of the Bretton Woods System itself.

Thus, history shows that this cartel, like most cartels, proved impossible to hold together when the need was greatest - that is, when collective action was needed for the maintenance of the system. The same point applies today: the countries of Asia are similarly unlikely to be able to subordinate their individual interest to the collective interest. It may be in their collective interest to hold dollars to keep their currencies down and the dollar up, but it is in their individual interest to get out before the bottom falls out of the U.S. currency. This, then, is a classic cartel problem. And there already are signs that the cartel is fraying around the edges. ${ }^{33}$

\footnotetext{
${ }^{30}$ This view has been popularized by Dooley, Folkerts-Landau and Garber (2003).

${ }^{31}$ As I have argued in Eichengreen (2004).

${ }^{32}$ I argue that the Gold Pool is more relevant than the bilateral agreements negotiated between the UK and the members of the sterling area in the 1930s because the UK guaranteed the value of sterling claims in dollars in return for promises of restrain by sterling area central banks, which greatly shaped the incentive problem. Clearly, a value-maintenance guarantee of this sort is not something that the United States would be prepared to extend today.

${ }^{33}$ For some suggestive evidence see Eichengreen (2005).
} 
What about the fact that the U.S. liquid liabilities held by foreign central banks are large relative to the foreign liquid assets of the Fed and the U.S. government? Doesn't this heighten the likelihood of a shift into alternative forms of reserves? By itself, this fact is not a threat to the reserve currency status of the dollar. In 1913, the liquid sterling claims held by official foreign institutions were $2 \frac{1}{2}$ times the Bank of England's gold reserves. ${ }^{34}$ After 1959 , official foreign holdings of dollars similarly exceeded the gold reserves of the United States. In both instances there was some talk of the difficulties that would arise if foreign creditors suddenly decided to liquidate these claims. But in neither case did wholesale liquidation occur, and in neither case was the status of the reserve currency seriously threatened. In each of these instances the accumulation of liquid claims on the reserve currency country was a natural corollary of that country's status as a financial center and of the rising demand for reserves created by a growing world economy.

One hears the same argument today. It is said that the U.S. is borrowing short and lending long because it has a more efficient financial system and because the countries on the other side of the intermediation process have a voracious demand for liquid foreign reserves. China buys U.S. treasury securities - liquid claims on the United States - and the U.S. turns around and uses the proceeds to fund less liquid foreign direct investment in China, circumventing the inefficiencies of the Chinese banking system. ${ }^{35}$ This, of course, is simply an updating of the Despres-Kindleberger-Salant (1966) view of the U.S. balance of payments in the 1960s. Emile Despres, Charles Kindleberger and Walter Salant argued that focusing on balance of payments statistics that put net long-term

\footnotetext{
${ }^{34}$ This is distinct from the ratio of total liquid liabilities to foreigners relative to total liquid assets held abroad, about which less is known and considerable controversy prevails. See Bloomfield (1963).

${ }^{35}$ As argued by Dooley, Folkerts-Landau and Garber (2004).
} 
foreign assets above the line but net short-term foreign assets below it is misleading when both components are in fact parts of the same intermediation process. ${ }^{36}$ The same was of course the case before $1914 .^{37}$ Then too, Britain borrowed short and lent long, acting as banker to the world. If there was no particular reason to worry then about the fact that liquid claims of foreign official creditors exceeded liquid foreign assets, it is said, then there is no reason to worry now.

But there is a difference between these two previous episodes and today, namely that the present situation occurs against the backdrop of large, ongoing current account deficits for the country that is banker to the world. In principle, there is no reason why the country with the most efficient financial system that is providing intermediation serves to the rest of the world cannot run a balanced current account or a surplus. There is no reason why importing short-term capital and exporting long-term capital should also require it to run a current account deficit, as the United States is doing. ${ }^{38}$ The U.S. ran current account surpluses following World War II, even after contemporaries stopped referring to the dollar gap. Similarly, Britain ran persistent current account surpluses before World War I. ${ }^{39}$

\footnotetext{
${ }^{36}$ Two sides of the same coin, as it were. Salant (1966) provides a statement of the view that the tendency of the U.S. to borrow short and lend long reflected the lower costs and greater efficiency of financial intermediation in the United States. The language there is almost identical to the rhetoric currently used to characterize the differences between the U.S. and Chinese financial sectors today.

${ }^{37}$ See Feis (1930), Lindert (1969) and Fishlow (1986).

${ }^{38}$ Arguably, on these previous occasions the reserve currency country was a net lender both on short- and long-term account (Bloomfield 1963). In the pre-1914 British case, for example, while the net short-term liabilities of the government and the central bank to their official foreign counterparts were positive, the net short-term liabilities of the country as a whole were probably negative, reflecting the large volume of private acceptance claims on foreigners (again, see Bloomfield 1963). The same may have been true of France and Germany, although less is known about these cases.

${ }^{39}$ Although prewar Britain ran a deficit on merchandise trade, net income from shipping, insurance, interest and dividends were more than sufficient to produce a substantial current account surplus. The other side of this coin was a substantial capital outflow: between 1900 and 1913 Britain invested some 5 percent of her GDP abroad. The country's net foreign assets were on the order of a quarter of GDP. France invested perhaps $2 \frac{1}{2}$ percent of her GDP abroad each year, and her net foreign asset ratio was perhaps half of
} 
Advocates of this banker-to-the-world view argue that other countries are running surpluses against the United States and accumulating reserves in the form of dollars because these serve as collateral for U.S. FDI. ${ }^{40}$ U.S. corporations are willing to build factories in China, in this view, because they know that if the Chinese authorities attempt to expropriate them, the U.S. government will freeze China's dollar reserves. In the $19^{\text {th }}$ century, gunboats provided this function. After World War II the U.S. nuclear umbrella did the same. Now it is the balance of financial terror.

I do not find this rationale for U.S. deficits very compelling. The story is China specific, where the accumulation of reserves and chronic surpluses vis-à-vis the United States is pan-Asian. And no one worries that Japan or South Korea will expropriate U.S. investments. I am not aware of U.S. corporate executives who have pointed to China's large dollar reserves as a form of collateral in justifying their decision to invest there. Nor am I aware of statements by Chinese officials in which they explain that they are accumulating U.S. Treasuries as a way of posting collateral for FDI inflows. Moreover,

Britain's. My own estimates (Eichengreen 2000b) suggest that the United States first became a net foreign creditor as a result of World War I, although the size of the net position was small. of the U.S. foreign net asset position circa 1950 put this at some $\$ 52$ billion, or about 20 percent of GDP. This is why contemporaries and historians were able to refer to the unparalleled pulling power of the Bank of England's discount rate. See for example Smit (1934). If foreigners began converting sterling reserves into gold - if Britain's liquid external liabilities and assets both began to fall - the country's long-term assets were easily liquefied. In particular, an increase in bank rate damped down, or at least delayed, long-term foreign lending. (In addition, it encouraged overseas and foreign residents floating bonds in London to maintain a larger share of the proceeds on deposit there, as already mentioned. Raising interest rates also raised interest earnings since the country was a net foreign creditor; that is, residents had more interest-earning assets abroad than foreigners maintained in Britain. And, on rare occasion, there was also the possibility of foreign support in the event that the Bank of England's liquid assets proved insufficient, as I have emphasized in Eichengreen (1995). For an earlier discussion of the same point see Bloomfield (1959).) It strengthened the balance of payments by contracting the volume of acceptances and other short-term claims on the rest of the world. The classic statement of this view is that of the Macmillan Committee (Committee on Finance and Industry 1931). Bloomfield (1963) provides a more agnostic approach to the question. The U.S. position in the 1960s was more tenuous because of the reluctance of the authorities to use the interest rate to defend the dollar owing to the potentially adverse impact of tighter money on employment and growth, as described in Eichengreen (2000b). But the government relied instead on taxes and voluntary restraints to discourage direct foreign investment by U.S. corporations, with much the same effect.

${ }^{40}$ See Dooley and Garber (2005). 
the timing is wrong: U.S. FDI in China rises starting around 1992, where the massive reserve accumulation comes only a decade later. Given the difficulty of identifying the final holders of U.S. treasury securities, it is not clear that selective default of this sort is possible. And given the fact that the U.S. accounts for only a small fraction of FDI in China, one must assume that the United States would be willing to compromise its public credit standing in this way on behalf not just of U.S. private foreign investors but also of those from other countries. Historically, the way foreign investments in China have been expropriated is through the surreptitious stripping of assets by Chinese managers and joint-venture partners. It is hard to imagine that the U.S. government would risk tarnishing its public credit in response to more such instances. Rather, one has to assume a major geopolitical blow-up between the U.S. and China, a decision by Beijing to freeze all U.S. investments there, and retaliation by the U.S. government in the form of freezing Chinese t-bill holdings. Such events are not beyond all realm of possibility, but they do not strike me as an obvious way of explaining the current pattern of global imbalances.

In my view, the fact that the reserve currency country is running current account deficits and incurring a large net foreign debt threatens to undermine its position as banker to the world. This means that long-term foreign claims on the U.S. are as easily liquefied as long-term U.S. claims on foreigners - even more so to the extent that longterm U.S. foreign assets take the form of illiquid FDI and U.S. long-term foreign liabilities take the form of treasury bonds. While there may be something to the "banker to the world" metaphor, now - unlike Britain before 1914 and the United States before 1971 - we are talking about a bank with a negative net capital. 
A modest net foreign debt may not be a problem, given the strength of the American economy and its attractions for foreign investors. The United States has other sources of strength, not merely its financial capital. But if its debt is allowed to grow relative to GDP, sooner or later foreigners will grow reluctant to hold more of it. That reluctance could lead to currency depreciation and inflation in the United States that ultimately makes holding reserves in dollars less attractive.

Michael Mussa (2004), in a recent analysis, provides a simple way of thinking about this. Mussa shows that the ratio of net foreign liabilities to GDP, denoted $n$, stabilizes when $c=n * g$, where $c$ is the current account deficit as a share of GDP and $g$ is the rate of growth of nominal income. If $\mathrm{g}$ is 0.05 (3 percent real growth plus two percent inflation) and $\mathrm{c}$ is 0.025 , then the debt ratio stabilizes at 50 percent, double the current 25 percent and perhaps the plausible upper bound on how much U.S. net debt foreigners might be willing to hold. (This is also what Mussa assumes, subject to some caveats. It will be useful for what follows to assume that inflation in the rest of the world also runs at 2 percent, the upper bound of the ECB's target range.) ${ }^{41}$

Assume now that the United States does nothing to raise its public and household savings rates and that the current account deficit is allowed to continue running at 5 percent of GDP. With $\mathrm{g}=0.05$ and $\mathrm{c}=0.05$, the debt ratio now stabilizes at 100 percent. ${ }^{42}$ This is a much higher ratio than ever incurred by a large country, much less by

\footnotetext{
${ }^{41}$ Comparable rates of inflation between these two large markets are of course consistent with the long-run stability of exchange rates between them.

${ }^{42}$ Or at least it stabilizes there under favorable assumptions. Note for example that I have said nothing about the increase in nominal interest rates that might accompany this higher inflation rate. Net interest payments to foreigners are part of the current account, of course. If they rise with inflation, as is plausible, then the trade balance must strengthen to keep the current account from rising above 5 percent. (And if the term of the debt shortens in response to the acceleration of inflation, the increase in interest liabilities becomes larger still, since the now-higher interest rate must be paid on a larger fraction of the outstanding debt.) If the trade balance doesn't strengthen, then the U.S. authorities have to respond with a further
} 
a reserve-currency country. It implies that foreigners would have to hold a considerably greater share of their portfolios than at present in the form of claims on the United States. This result, in other words, is implausible. Something has to give.

One way of squaring the circle, assuming no change in $c$, which is what we are assuming for the moment, is to raise the rate of inflation from, say, 2 to 7 per cent, with the result that the rate of nominal income growth rises 5 to 10 percent. ${ }^{43}$ With $c=0.05$ and $g=.10, n$ again stabilizes at 50 percent, which we are assuming to be the upper bound. The most likely way in which this would come about is that foreigners would grow unwilling to add more dollar-denominated securities to their portfolios. Keeping the share of dollar-denominated securities in foreign portfolios constant, even while the U.S. continues to pump additional treasury bonds into the world economy, requires the dollar exchange rate to fall. ${ }^{44}$ And once it begins falling, there may be a "rush out of dollars," as investors scramble out in order to avoid ending up holding the bag (that is, to avoid incurring large capital losses as a result of being late). And the faster the dollar drops, the greater are imported inflation and upward pressure on U.S. inflation generally. This is how market forces produce the acceleration in inflation that limits the U.S. external debt/GNP ratio to levels acceptable to investors.

Some will object at this point that the Fed would not be prepared to countenance such an acceleration in inflation. They have in mind that it would raise interest rates sharply in order to damp down the additional inflationary pressure. But whether this provides a smooth way out of the dilemma at hand depends on how we think the Fed's

surprise increase in inflation, which presumably elicits an increase in interest rates, and so forth in a vicious spiral. Presumably this would render the dollar a still less attractive form in which to hold reserves.

${ }^{43}$ The assumption that real growth remains unchanged is a convenient simplification to which we may wish to return below.

${ }^{44}$ This is the classic portfolio-balance model of international adjustment, as in Kouri (1976). 
higher interest rates will affect the economy and the current account. Sharply higher interest rates would depress both absorption and output. ${ }^{45}$ They would depress consumer spending through their negative impact on house prices and the value of other assets and depress investment by raising the cost of capital. They would depress the growth of output through their negative effects on investment and aggregate demand generally. If the main thing that falls is absorption, then the current account will narrow and portfolio equilibrium can be restored without rapid inflation. But if the main thing that falls is output, then the current account - the current account being the difference between absorption and output - may show little if any improvement. Higher interest rates that depress output may then also destabilize the financial system; after all, the combination of higher interest rates and a collapsing exchange rate, occurring against the backdrop of chronic fiscal and external imbalances, is the classic recipe for a financial crisis.

None of these scenarios have happy endings for the reserve currency role of the dollar. Assume first that the Fed does not attempt to offset the inflationary effects of the fall of the dollar. With U.S. inflation now running at three times inflation in other countries, using the dollar as a store of value and a vehicle and invoicing currency would become less attractive. ${ }^{46}$ The resulting capital losses would eventually encourage foreign central banks and governments to find a more stable repository for their reserves. ${ }^{47}$ Alternatively, assume that the Fed raises the discount rate sharply in order to prevent an

\footnotetext{
${ }^{45}$ Here is where the assumption flagged in the previous footnote should be relaxed.

${ }^{46}$ A point emphasized by Tavlas (1997). If we instead assume that $\mathrm{n}$ must stabilize at 40 percent of U.S. GDP, Mussa's more conservative estimate of the feasible, then U.S. inflation must rise to 10.5 percent, more than five times foreign levels, which only reinforces the conclusion.

${ }^{47}$ A complication here is that depreciation of the dollar also has the effect of reducing the U.S. net external debt because U.S. foreign assets are disproportionately denominated in foreign currencies (as in the case, in some sense, of foreign direct investments) while U.S. foreign liabilities are disproportionately denominated in dollars (as emphasized by Gourinchas and Rey 2003 and Lane and Milesi-Ferretti 2004). But this too is likely to change in an environment of higher inflation and secular depreciation like that emphasized in the text.
} 
acceleration of inflation. This might only precipitate a sharp recession and financial distress - and potentially an even sharper drop in the dollar. This would again lead foreign central banks and other investors to shift out of dollars to avoid capital losses. ${ }^{48}$ Only if we assume that the Fed can engineer a smooth landing - that it could raise interest rates just enough to contain inflation but without precipitating a serious recession and thereby reduce $c$ after all - would there be a smooth way out.

$$
* * * *
$$

What does this imply for the reserve currency role of the dollar? It implies that whether the dollar retains its reserve currency role depends, first and foremost, on America's own policies. Serious economic mismanagement would lead to the substitution of other reserve currencies for the dollar. In this context, serious mismanagement means policies that allow unsustainably large current account deficits to persist, lead to the accumulation of large external debts, and result in a high rate of U.S. inflation and dollar depreciation. Clearly, this would make holding dollar reserves unattractive. This is a lesson of British history in the sense that an inflation rate that ran at roughly 3 times U.S. rates over the first three quarters of the $20^{\text {th }}$ century, in conjunction with repeated devaluations against the dollar, played a major role in sterling's loss of reserve currency status.

\footnotetext{
${ }^{48}$ The possibility that sharp interest rate increases that caused recession and financial distress could weaken the currency rather than strengthening it of course was much discussed in the aftermath of the Asian crisis. See for example Furman and Stiglitz (1998). The careful reader will have noted that the first scenario has both inflation and currency depreciation accelerating, while the second has currency depreciation accelerating without a concurrent increase in inflation. The reason is that the real exchange rate has good reason to behave differently in the two scenarios; in the second one real depreciation is required to begin crowding in the demand for U.S. goods.
} 
Under the more optimistic scenario in which the U.S. current account deficit is brought under control, there is no obvious reason why the dollar should lose its reserve currency status, given the stability of U.S. policy, the vibrancy of the U.S. economy, and the liquidity of U.S. financial markets. But this does not mean that the dollar will remain as dominant as in the past. As financial markets in other countries gain liquidity, their currencies become more convenient forms in which to hold reserves. For more than four decades after World War II, as I emphasized above, other countries maintained capital controls and tight financial regulations that limited the liquidity of their markets, rendering their currencies less attractive as repositories for reserves and accentuating the dominance of the dollar. Now, with financial normalization and liberalization, some diversification out of dollars is inevitable. This does not mean that the dollar is doomed to lose its reserve currency status. The network-externalities argument that competition for reserve currency status is a winner-take-all game holds little water either analytically or historically. Looking forward, financial innovation will continue to reduce the costs of converting currencies, further reducing the incentive to hold reserves in the same form that other countries hold reserves simply in order to minimize transactions costs. Thus, there is no reason why, several decades from now, two or three reserve currencies cannot share the market, not unlike the situation before $1914 .^{49}$

But which currencies? Unsurprisingly, my candidates, whether we are thinking of 2020 or 2040, are the dollar and the euro. Both Europe and the U.S. have strong institutions, respect for property rights, and sound and sound macroeconomic policies relative to the rest of the world. They have stable political systems. Their economies are likely to be of roughly equal size, to engage in similar levels of external trade and

\footnotetext{
${ }^{49}$ Another statement of this view is Issing (2003).
} 
financial transactions, and to have comparably liquid securities markets. The advent of the euro has done much to increase the liquidity of European bond markets, which is a critical event from the point of view of enhancing the reserve currency status of the euro. ${ }^{50}$ The only question is whether the soundness of macroeconomic policies will be maintained in the United States or whether dollar's reserve currency status could be destroyed by an extended bout of inflationary.

The other popular candidates are not likely to be major rivals. Japan is a much smaller country with a serious demographic problem and a resistance to immigration. Nor has it displayed a record of policy stability in recent years. Everyone's favorite heir to the throne, China, will have to solve some very serious problems before its currency begins to become attractive as a repository for other countries' foreign exchange reserves. Removing capital controls is the least of its problems, in my view. Its financial markets are not very liquid or transparent; indeed, most of the institutional infrastructure needed for Shanghai to become a true international financial center will take decades to install. The security of property rights is uncertain, and making investors feel secure will ultimately require a transition to democracy, the creation of credible political checks and balances, and the development of a creditor class with political sway. While the renminbi is everyone's favorite candidate for the new reserve currency champion four or five decades from now, such hopes are, in my opinion, still highly premature.

Thus, my message, appropriate for this venue, is that history must be read carefully. In fact, several currencies can share reserve currency status, as they not infrequently have. Changes in financial technologies and market structures, which weaken network effects, make it even more likely that this will be true in the future than

\footnotetext{
${ }^{50}$ See Pagano and von Thadden (2004).
} 
the past. At the same time, mistaken policies can quickly knock a currency out of contention. Time will tell whether this fate befalls the dollar. 


\section{References}

Balogh, Thomas (1950), Studies in Financial Organization, Cambridge: Cambridge University Press.

Bell, Philip (1956), The Sterling Area in the Postwar World, Oxford: Clarendon Press.

Bloomfield, Arthur I. (1959), Monetary Policy under the International Gold Standard 1880-1914, New York: Federal Reserve Bank of New York.

Bloomfield, Arthur I. (1963), "Short-Term Capital Movements under the Pre-1914 Gold Standard," Princeton Studies in International Finance no. 11, International Finance Section, Department of Economics, Princeton University.

Bordo, Michael, Christopher Meissner and Angela Redish (2005), "How Original Sin was Overcome: The Evolution of External Debt Denominated in Domestic Currencies in the United States and the British Dominions," in Barry Eichengreen and Ricardo Hausmann, eds, Other People's Money: Debt Denomination and Financial Stability in Emerging Market Economies, Chicago: University of Chicago Press, pp. 122-153.

Broz, Lawrence (1997), The International Origins of the Federal Reserve System, Ithaca: Cornell University Press.

Cohen, Benjamin J. (1971), The Future of Sterling as an International Currency, London: Macmillan.

Committee on Finance and Industry [Macmillan Committee] (1931), Report, London: HMSO.

Crick, W.F. (1948), Origins and Development of the Sterling Area, London: Institute of Bankers.

Despres, Emile, Charles Kindleberger and Walter Salant (1966), “The Dollar and World Liquidity: A Minority View," The Economist 218 (5 February).

Dooley, Michael, David Folkerts-Landau and Peter Garber (2003), "An Essay on the Revived Bretton Woods System,” NBER Working Paper no. 9971 (September).

Dooley, Michael, David Folkerts-Landau and Peter Garber (2004), "Direct Investment, Rising Real Wages and the Absorption of Excess Labor in the Periphery," NBER Working Paper no. 10626 (July).

Dooley, Michael and Peter Garber (2005), "Is it 1958 or 1968? Three Notes on the Longevity of the Revived Bretton Woods System," Brookings Papers on Economic Activity (forthcoming). 
Eichengreen, Barry (1995), "Exchange Rate Commitments and Central Bank Cooperation: The Classical and Interwar Gold Standard Compared," Financial History Review 2, pp. 99-117.

Eichengreen, Barry (1998), “The Euro as a Reserve Currency," Journal of the Japanese and International Economies 12, pp. 483-506.

Eichengreen, Barry (2000a), "U.S. Foreign Financial Relations in the Twentieth Century," in Stanley Engerman and Robert Gallman eds, The Cambridge Economic History of the United States, Volume III: The Twentieth Century, Cambridge: Cambridge University Press, pp. 463-504.

Eichengreen, Barry (2000b), "From Benign Neglect to Malignant Preoccupation: U.S. Balance of Payments Policy in the 1960s," in George L. Perry and James Tobin eds, Economic Events, Ideas and Policies: The 1960s and After, Washington, D.C.: The Brookings Institution, pp. 185-242.

Eichengreen, Barry (2004), "Global Imbalances and the Lessons of Bretton Woods," NBER Working Paper no. 10497 (May).

Eichengreen, Barry (2005), "The Dollar and the New Bretton Woods System," Thornton Lecture delivered at the Cass School of Business, City University, www.emlab.berkeley. edu.

Feis, Herbert (1930), Europe, the World's Banker, New Haven: Yale University Press.

Fishlow, Albert (1986), "Lessons from the Past: Capital Markets during the $19^{\text {th }}$ Century and the Interwar Period," in Miles Kahler ed., The Politics of International Debt, Ithaca: Cornell University Press, pp. 37-94.

Furman, Jason and Joseph Stiglitz (1998), "Economic Crises: Evidence and Insights from East Asia," Brookings Papers on Economic Activity 2, pp.1-135.

Flandreau, Marc and Nathan Sussman (2005), "Old Sins: Exchange Clauses and European Foreign Lending in the Nineteenth Century," in Barry Eichengreen and Ricardo Hausmann, eds, Other People's Money: Debt Denomination and Financial Stability in Emerging Market Economies, Chicago: University of Chicago Press, pp. 154-189.

Gourinchas, Pierre-Olivier and Helene Rey (2003), "International Financial Adjustment," unpublished manuscript, University of California, Berkeley and Princeton University.

Imlah, Albert (1958), Economic Elements in the Pax Britannica, Cambridge, Mass.: Harvard University Press.

Issing, Otmar (2003), "The Euro - a Stable International Currency," speech to the Hungarian Academy of Sciences, Budapest, 27 February, www.ecb.int/press. 
Kouri, Pentti (1976), "The Exchange Rate and the Balance of Payments in the Short Run and in the Long Run: A Monetary Approach," Scandinavian Journal of Economics 78, pp.280-304.

Lane, Philip and Gian Maria Milesi-Ferretti (2004), "Financial Globalization and Exchange Rate Changes," IMF Working Paper 05/03 (January).

Lindert, Peter H. (1969), "Key Currencies and Gold 1900-1913,” Princeton Studies in International Finance no. 24, International Finance Section, Department of Economics, Princeton University.

Matsuyama, K., N. Kiyotaki and A. Matsui (1993), “Toward a Theory of International Currency," Review of Economic Studies 60, pp. 283-307.

Mussa, Michael (2004), "Exchange Rate Adjustments Needed to Reduce Global Payments Imbalances," in C. Fred Bergsten and John Williamson, Dollar Adjustment: How Far? Against What? Washington, D.C.: Institute for International Economics, eds, pp. 113-138.

Nurkse, Ragnar (1944), International Currency Experience, Geneva: League of Nations.

Pagano, Marco and Ernst-Ludwig von Thadden (2004), "The European Bond Markets Under EMU," CSEF Working Paper no. 126, Center for Studies in Economics and Finance, University of Salerno.

Persaud, Avinash (2004), "When Currency Empires Fall," www.321gold.com/ editorials (11 October).

Rajan, Raghuram and Luigi Zingales (2003), "The Great Reversals: The Politics of Financial Development in the $20^{\text {th }}$ Century," Journal of Financial Economics 114, pp. 550.

Redish, Angela (1990), “The Evolution of the Gold Standard in England," Journal of Economic History 50, pp. 789-805.

Salant, Walter S. (1966), "Capital Markets and the Balance of Payments of a Financial Center," in William Fellner, Fritz Machlup and Robert Triffin, eds, Maintaining and Restore Balance in International Payments, Princeton: Princeton University Press, pp. 177-196.

Sayers, Richard (1976), The Bank of England, 1891-1944, Cambridge: Cambridge University Press.

Schenk, Catherine R. (2004), "The Empire Strikes Back: Hong Kong and the Decline of Sterling in the 1960s," Economic History Review LVII, pp.551-580. 
Smit, Carel Jan (1934), “The Pre-War Gold Standard,” Proceedings of the American Political Science Association 16, pp. 53-56.

Tavlas, George (1997), "The International Use of the US Dollar: An Optimum Currency Area Perspective," The World Economy 20, pp. 709-747.

Triffin, Robert (1964), “The Evolution of the International Monetary System: Historical Reappraisal and Future Perspectives," Princeton Studies in International Finance no. 12, International Finance Section, Department of Economics, Princeton University.

Williams, David (1968), "The Evolution of the Sterling System," in C.R. Whitlesey and J.S.G Wilson, eds, Essays in Money and Banking, Oxford: Oxford University Press, pp. 266-297.

Wilson, Charles H. (1941), Anglo-Dutch Commerce and Finance in the Eighteenth Century, Cambridge: Cambridge University Press. 
Table 1

Shares of Currencies in Known Official Foreign Exchange Assets, 1899-1913

\begin{tabular}{lcc}
\hline & End of 1899 & End of 1913 \\
\hline Sterling & 64 & 48 \\
Francs & 16 & 31 \\
Marks & 15 & 15 \\
Other currencies & 6 & 6 \\
\hline
\end{tabular}

Notes: Percentages may not sum to 100 due to rounding.

Source: Calculated from Lindert (1969), Table 3. 


\section{Table 2}

Currency composition of foreign exchange reserves

\begin{tabular}{lcccc}
\multicolumn{5}{c}{ (in percent) } \\
\hline \multicolumn{1}{c}{ Regime } & 1973 & 1987 & 1995 & 2002 \\
\hline \hline US dollar & 84.5 & 66.0 & 56.4 & 64.8 \\
Euro & - & - & - & 14.6 \\
Sterling & 5.9 & 2.2 & 3.4 & 4.4 \\
German mark & 6.7 & 13.4 & 13.7 & - \\
French franc & 1.2 & 0.8 & 1.8 & - \\
Swiss franc & 1.4 & 1.5 & 0.1 & 0.7 \\
Yen & - & 7.0 & 7.1 & 4.5 \\
ECU & - & 5.7 & 6.5 & - \\
Other & - & 3.4 & 9.7 & 20.6 \\
\hline
\end{tabular}

Source: IMF. 